HELMINTHOLOGIA, 57, 4: 394 - 401, 2020

Research Note

\title{
Three species of Xiphinema americanum-group complex (Nematoda: Longidoridae), from Lorestan province, Iran
}

\author{
E. BAZGIR, A. NAGHAVI*, Z. ZOLFAGHARI
}

Nematology Laboratory, Department of Plant Protection, Faculty of Agriculture, Lorestan University, Khorramabad, Iran, *E-mail:ar_ng11@yahoo.com

Article info

Received May 15, 2020

Accepted July 14, 2020

\section{Summary}

The dagger nematodes of the longidorids can cause diseases of various agronomic and horticultural crops, and are consisted of more than 260 valid species. In a forest survey of ecotypes of longidorid nematodes, from the root zone soil of Brant's oak, (Quercus brantii Lindl.) and hawthorn (Crataegus aronia L.) trees, three species of Xiphinema americanum group namely Xiphinema pachtaicum, $X$. oxycaudatum and $X$. plesiopachtaicum were collected and studied based on their morphological and morphometric characters. $X$. pachtaicum is prevalent Xiphinema species in Iran. In this paper additional data for $X$. oxycaudatum and $X$. plesiopachtaicum species are presented. $X$. plesiopachtaicum is a new record for nematode fauna of Iran.

Keywords: dagger nematodes; oak; hawthorn; X. oxycaudatum; X. plesiopachtaicum; new record

\section{Introduction}

The tribe Longidorini which is a subfamily of Longidorinae (Longidorus spp. and Paralongidorus spp.) accompanied with subfamily Xiphineminae (Xiphinema spp.) are two major plant parasitic nematode groups. Dagger nematodes of the longidorids comprise of plant-parasitic species that cause damage to a vast range of wild and cultivated plants either directly through feeding on plant root cells or indirectly via vectoring of nepoviruses to a wide range of fruit and vegetable crops (Taylor \& Brown, 1997; Gutierrez-Gutierrez et al., 2016). The genus Xiphinema has been divided to the $X$. americanum and $X$. non-americanum groups. $X$. americanum morpho-groups can be characterized by a spiral or C-shaped, small body (1 - $3 \mathrm{~mm}$ ). Odontostyle $60-20 \mu \mathrm{m}$. Female reproductive system with two equally developed genital branches, short uteri without uterine differentiation. Presence of symbiotic bacteria in intestinal cells of some juveniles and occasionally in the ovaries of adults. Tail short conical to broadly convex-conoid (Lamberti et al., 2000; Orlando et al., 2016).
The Xiphinema americanum-group consisted of a complex of about 55 species of plant-ectoparasitic nematodes of plants. This group of plant-parasitic nematodes is one of the most difficult Xiphinema species complexes to be diagnosed, because their morphology is very conservative and their morphometric characters are often overlaped (Archidona-Yuste et al., 2016). Ten species of Xiphinema have been reported from Iran. They are $X$. americanum, $X$. bacaniboia, $X$. brevicollum, $X$. himalayense, $X$. oxycaudatum, $X$. pachtaicum, $X$. pacficum and $X$. rivesi (Ghaderi et al., 2018), X. simile (Naghavi et al., 2018) and X. primum (Mobasseri, et al., 2020). In the present nematological survey on longidorids in Khorramabad county, Lorestan province, southwest of Iran, three nematode species of the genus Xiphinema namely $X$. oxycaudatum, $X$. pachtaicum and $X$. plesiopachtaicum were collected from several natural environments and were identified based on morphological and morphometrics characters and out of this three nematode species, $X$. plesiopachtaicum is a new record for nematode fauna of Iran.

\footnotetext{
* - corresponding author
} 


\section{Material and Methods}

The present survey carried out in forests of Khorramabad district, Lorestan province, south west of Iran, during spring 2018 till late autumn 2019. Khorramabad is located in the middle parts of Zagros Mountain ranges of Iran, due to receiving more than 500 $\mathrm{mm}$ precipitation on average annually, it enjoys a rich diversity of plant coverage, including Oaks and hawthorns forest trees. GPS coordinates of the sampling location were: $33^{\circ} 29^{\prime} 15^{\prime \prime}$ E $48^{\circ} 21^{\prime}$ $15 "$. After removing the upper $5 \mathrm{~cm}$ of topsoil, 80 Soil samples were randomly collected from 20 to $50 \mathrm{~cm}$ depth of the rhizosphere of Brant's oak (Quercus brantii Lindi.) and hawthorn (Crataegus aronia L.) forest trees. Keeping $50 \mathrm{~cm}$ distance from the trees, four soil samples collected from 4 main geographic directions around the tree stems. The soil samples were thoroughly mixed on clean plastic sheet, and about $1 \mathrm{~kg}$ of the mixed soil samples were poured in plastic bag as a composite sample. The bag labeled for location, date and tree species of sample collection. Then the bags transferred to the nematology laboratory of Plant protection Department of Lorestan University and they were stored at $4{ }^{\circ} \mathrm{C}$ until their processing. Nematodes extraction carried out from $500 \mathrm{~cm}^{3}$ of soil samples using the Brown \&Boag (1988) modified method. Additional soil samples were collected if needed afterwards, from the same locations to obtain sufficient specimens for morphological characterization. Specimens for light microscopy were killed using gentle heat, then fixed and processed to pure glycerin adopting the De Grisse (1969) method. Morphological and morphometric criteria of specimens were studied using an Olympus BX31 light microscope equipped with a Dino-eye microscope eye-piece camera in conjunction with Dino Capture version 2.0 software. Raw photographs were edited using Picasa 3.9.138.150. Drawings were made using Corel DRAW ${ }^{\circledR}$, software version 12.

\section{Ethical Approval and/or Informed Consent}

The conducted research is neither related to human nor animals use.

Table 1. Morphometrics of the Khorramabad, Iran populations of Xiphinema species. All measurements are in $\mu m$ (except $L$ in $m m)$, and in the form: mean \pm s.d. (range).

\begin{tabular}{lccc}
\hline Species & X. oxycaudatum & X. pachtaicum & X. plesiopachtaicum \\
\hline Characters ratios $^{*}$ & Female & Female & Female \\
$\mathrm{n}$ & 2 & 4 & 4 \\
$\mathrm{~L}$ & $1.5,1.7$ & $1.87-1.93(1.90 \pm 0.02)$ & $1.76-1.81(1.79 \pm 0.01)$ \\
$\mathrm{a}$ & 43,43 & $56.5-62.5(58.2 \pm 2.2)$ & $61.2-66.7(63 \pm 2.1)$ \\
$\mathrm{b}$ & 6,6 & $5.5-6.2(5.8 \pm 0.3)$ & $5.4-6(5.7 \pm 0.3)$ \\
$\mathrm{C}$ & $50,54.5$ & $63.2-65.7(64.5 \pm 1.1)$ & $59-66(62.6 \pm 2.5)$ \\
$\mathrm{c}^{\prime}$ & $1.3,1.4$ & $1.6-1.8(1.7 \pm 0.1)$ & $1.4-1.6(1.5 \pm 0.1)$ \\
$\mathrm{V}$ & 51,51 & $57-58(57.5 \pm 0.5)$ & $57-59(58 \pm 0.8)$ \\
Odontostyle length & $79.5,81.3$ & $82-85.5(82.8 \pm 0.5)$ & $73-76(74.4 \pm 1.2)$ \\
Odontophore length & $43.6,46.2$ & $44.5-49(47.5 \pm 1.1)$ & $42-43.7(42.9 \pm 0.7)$ \\
Spear length & $124.9,125.2$ & $128-133.8(130 \pm 2.5)$ & $116-118.8(117.5 \pm 1.1)$ \\
Lip region diam. & $10.5,11.5$ & $8.8-9(8.9 \pm 0.1)$ & $8.5-9.2(9 \pm 0.1)$ \\
Oral aperture to guide ring & $69.5,72$ & $75-79.5(77.9 \pm 1.1)$ & $64.5-68(66.4 \pm 1.1)$ \\
Pharynx length & $276,282.3$ & $303.5-343(319 \pm 15)$ & $297-330.5(310.9 \pm 8.5)$ \\
Pharyngeal bulb length & 68,74 & $67-82.5(74 \pm 6)$ & $71-81(76.1 \pm 4)$ \\
Body diam. at phar. base & $31,33.5$ & $26.5-31.3(28.6 \pm 1.8)$ & $27-29.5(28.2 \pm 1)$ \\
at mid-body & $35,39.5$ & $30-33(31.9 \pm 1.1)$ & $27-29.5(28.2 \pm 1)$ \\
at anus & $20,24.5$ & $16.5-17(16.7 \pm 0.2)$ & $18.3-19.1(18.7 \pm 0.2)$ \\
Tail length & $28.5,34$ & $29-30.5(29.5 \pm 0.3)$ & $27.5-30.6(28.7 \pm 1.1)$ \\
Hyaline of tail tip & $9,9.5$ & $9.5-10.7(10.3 \pm 0.2)$ & $5.6-7(6.5 \pm 0.4)$ \\
\hline
\end{tabular}

${ }^{*} n=$ number of females, full body length (L), body length/greatest body width (a), body length/pharyngeal length (b), body length/tail length (c), tail length/tail diameter at anus region ( $\mathrm{C}^{\prime}$ ) and \% distance of vulva from anterior end/body length (V). 


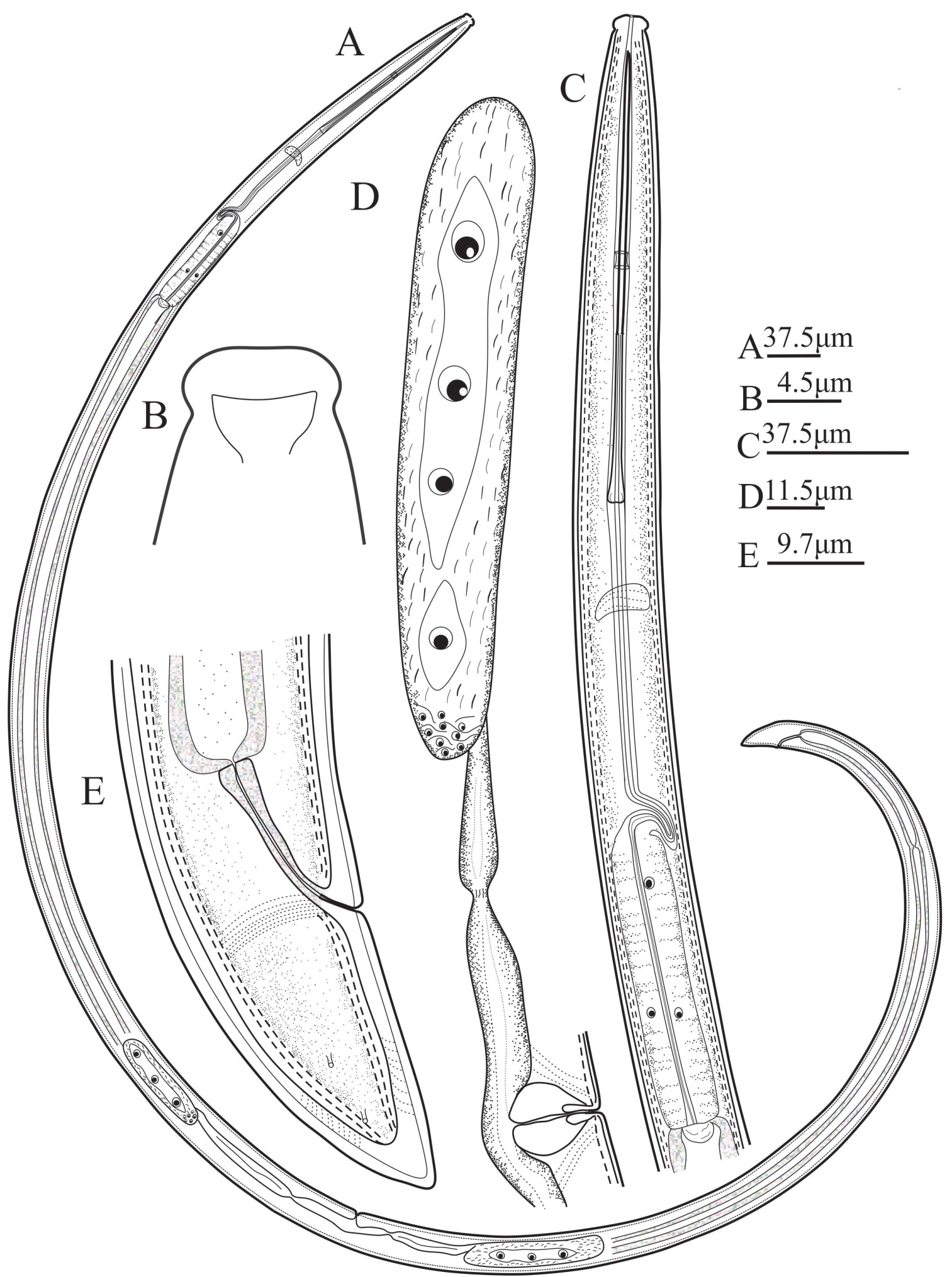

Fig. 1. Xiphinema plesiopachtaicum Archidona-Yuste, Navas-Cortes, Cantalapiedra-Navarrete, Palomares-Rius and Castillo, 2016: A: Entire body, B: Amphid, C: Head, Stylet and Pharynx, D: Anterior genital branch of the female reproductive system and symbiotic bacteria in ovary, E: Posterior end of body. 
Results and Discussion

Xiphinema plesiopachtaicum Archidona-Yuste, Navas-Cortes, Cantalapiedra-Navarrete, Palomares-Rius and Castillo, 2016

(Figs. 1, 3)

Measurements

See Table 1.

\section{Description \\ Female}

Body medium-sized $1.7-1.8 \mathrm{~mm}$, ventrally arcuate upon fixation, tapering toward both ends, habitus usually open $\mathrm{C}$ shaped after fixation. Labial region $3.6-3.8 \mu \mathrm{m}$ high, expanded, frontally flattened, laterally rounded, separated from the rest of the body by constriction. Amphid stirrup-shaped 5.5 - $6 \mu \mathrm{m}$ wide and $63-66 \%$ of the corresponding lip region diameter. Odontostyle 8, 8.4 times lip region diameter, odontophore 0.5 times odontostyle with weak flanges $6-7.5 \mu \mathrm{m}$ wide diameter. Pharynx dorylaimoid with basal bulb occupying ca $23-25 \%$ of the total length, muscular bulb measuring $11.4-12.3 \times 74-81 \mu \mathrm{m}$. The female reproductive system didelphic-amphidelphic, reflexed, both branches apparently equally developed, anterior and posterior genital branch $225-285 \mu \mathrm{m}$ and $230-280 \mu \mathrm{m}$ long, respectively, ovaries filled with symbiontic bacteria, vulva equatorial, transverse, slitlike, vagina with short distal part and very well developed proximal Part, $57-60 \%$ of corresponding body diam. Prerectum $415-$ $490 \mu \mathrm{m}$ long. Rectum $18.5-20 \mu \mathrm{m}$ long. Tail short, dorsoventral depression at hyaline region level, two pairs of caudal pores are present on each side.

Male: Not found.

\section{Distribution}

Faculty of Agriculture and Natural Resources, Khorramabad County, Lorestan province, Iran, (GPS coordinates: N $33^{\circ} 26^{\prime} 17^{\prime \prime}$ E $48^{\circ} 15^{\prime} 41^{\prime \prime}$, altitude $1769 \mathrm{~m}$ a.s.I.), in the root zone soil of oak (Quercus brantii Lindi.).

\section{Remarks}

$X$. plesiopachtaicum, is reported for the second time since its original description and for the first time outside Spain. The species X. plesiopachtaicum described by Archidona-Yuste et al., 2016 from the rhizosphere of olive trees in southern Spain for the first time. The present population fits well with the type specimens in most morphological and morphometric characteristics, only slight differences were observed viz shorter odontostyle $(73-76$ vs $77-89 \mu \mathrm{m})$ and longer tail $(27.5-30$ vs $23.5-28.5 \mu \mathrm{m})$. Based on the morphological similarities, $X$. plesiopachtaicum is closely related to X. Pachtaicum (Tulaganov, 1938) Kirjanova, 1951, $X$. madeirense Brown, Faria, Lamberti, Halbrendt, Agostinelli and Jones, 1988, X. parapachydermum Gutierrz-Guterrez, Cantalapiedra-Navarrete, Decramer, Vovlas, Prior, Palomarres \&
Castillo, 2012 and X. peruvianum Lamberti and Bleve-Zacheo, 1979. X. plesiopachtaicum could be separated from $X$. pachtaicum in having a smaller a $(61.2-66.7$ vs $64-74)$ and $c^{\prime}(1.4-1.6$ vs $1.7-2)$ ratio and shorter odontostyle $(73-76$ vs $77.6-81.6$ $\mu \mathrm{m})$. It can also be differentiated from $X$. madeirense via a shorter body length (1.7-1.8 vs $2-2.4 \mathrm{~mm}$ ), anteriorly located guiding ring $(64.5-68$ vs $82-98 \mu \mathrm{m})$, shorter odontostyle $(73-76$ vs $100-109 \mu \mathrm{m})$ and shorter tail $(27.5-30.6 v s 33-44 \mu \mathrm{m})$. It differs from $X$. parapachydermum by smaller $c^{\prime}$ value $(1.4-1.6$ vs $1.5-2.3)$, shorter odontostyle (73- 76 vs $70-87.5 \mu \mathrm{m})$ and odontophore (42 - 43.7 vs $36.5-54.5 \mu \mathrm{m})$. Finally, $X$. plesiopachtaicum can be differentiated from $X$. peruvianum by greater a value $(61.2-66.7$ vs $45-56)$, shorter odontostyle (73- 76 vs $85-92 \mu \mathrm{m}$ ) and odontophore (42 - 43.5 vs $46-52$ $\mu \mathrm{m})$, narrower lip region ( $8.5-9.2$ vs $9-10.5 \mu \mathrm{m})$ and anteriorly located guiding ring (64.5- 68 vs $67-78 \mu \mathrm{m})$.

\section{Xiphinema oxycaudatum Lamberti \& Bleve-Zacheo, 1979}

(Figs. 2, 3)

Measrements

See Table 1.

\section{Description}

\section{Female}

Body medium-sized 1.5, $1.7 \mathrm{~mm}$, tapering gradually toward the extremities. Labial region rounded separated by a constriction from the rest of the body. Amphidial pouches stirrup-shaped, with slitlike aperture, 4.2, $4.5 \mu \mathrm{m}$ wide, 39, $40 \%$ of the corresponding lip region diameter. Odontostylet, odontophore and guiding apparatus typical for $X$. americanum-group, odontostyle robust,7, 7.5 times lip region diameter, odontophore 0.5 times odontostyle with weak flanges, 8.6, $9 \mu \mathrm{m}$ wide diameter. The oesophageal basal bulb occupies ca $24,26 \%$ of the oesophagus total length, muscular bulb measuring 15.6, $18.8 \times 68.7,70 \mu \mathrm{m}$. The female reproductive system didelphic-amphidelphic with equally developed genital branches, anterior and posterior gonad 200, $264 \mu \mathrm{m}$ and 239, $255 \mu \mathrm{m}$ long, respectively, reflexed ovary filled with symbiotic bacteria, vulva transverse, equatorial, vagina occupying 47 , $48 \%$ of corresponding body diam. Tail, conoid, dorsally convex, ventrally straight to slightly arcuate with pointed terminus, bearing two caudal pores on each side.

Male: Not found

\section{Distribution}

Faculty of Agriculture and Natural Resources, Khorramabad County, Lorestan province, Iran, (GPS coordinates: N 33 $26^{\circ} 17^{\prime \prime}$ E $48^{\circ} 15^{\prime} 41^{\prime \prime}$, altitude $1769 \mathrm{~m}$ a.s.I.), in the root zone soil of oak (Quercus brantii Lindi.).

\section{Remarks}

This species was previously recorded from rhizosphere of oil palm 


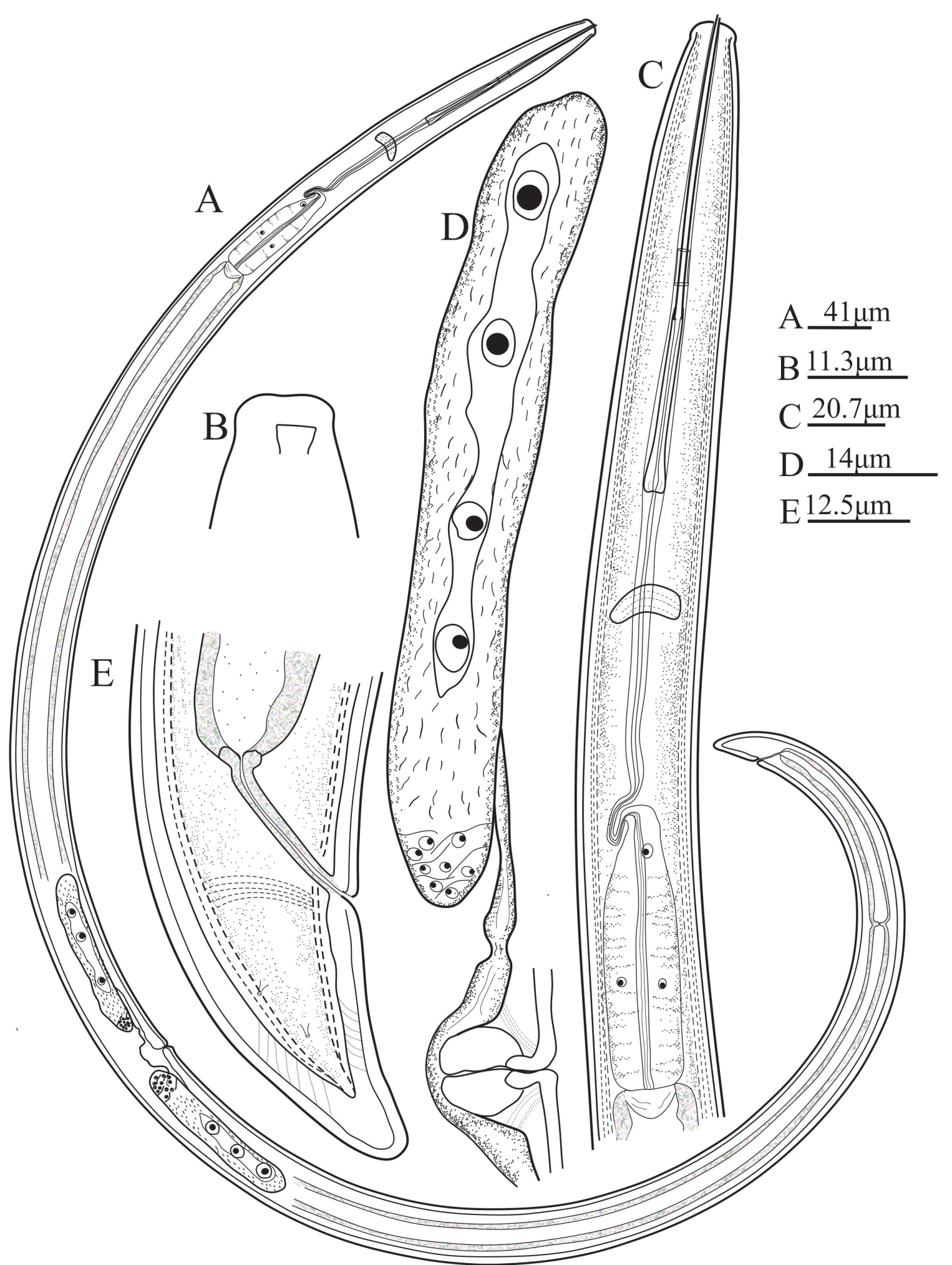

Fig. 2. Xiphinema oxycaudatum Lamberti \& Bleve-Zacheo, 1979: A: Entire body, B: Amphid, C: Head, Stylet and Pharynx, D: Anterior genital branch of the female reproductive system and symbiotic bacteria in ovary, E: Posterior end of body. 

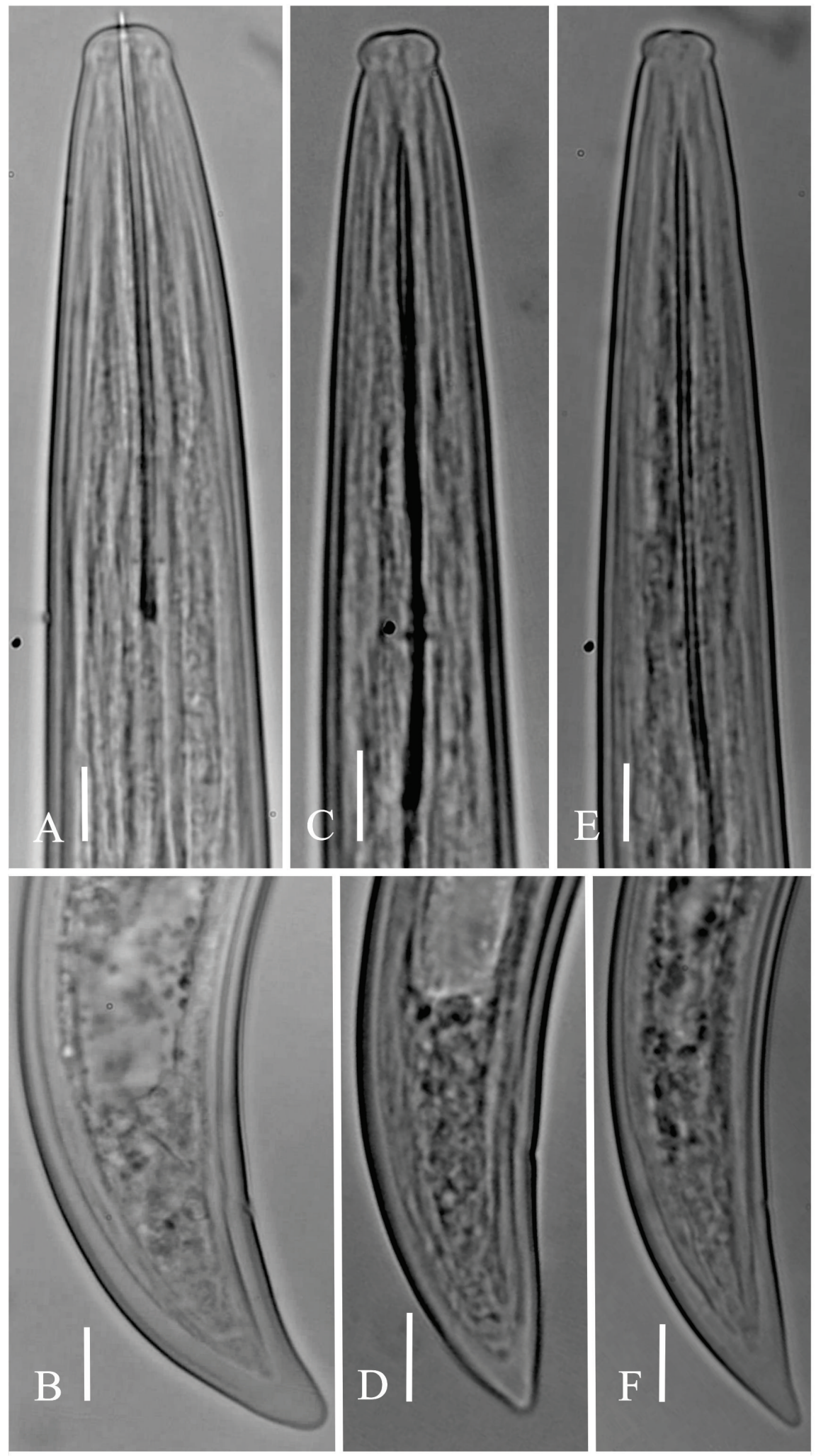

Fig. 3. A and B: X. oxycaudatum Lamberti \& Bleve-Zacheo, 1979, C and D: X. plesiopachtaicum Archidona-Yuste, Navas-Cortes, Cantalapiedra-Navarrete, Palomares-Rius and Castillo, 2016, E and F: X. pachtaicum (Tulaganov, 1938) Kirjanova, 1951 (Scale bar: A-F=10 $\mu \mathrm{m}$ ). 
in Nigeria (Lamberti \& Bleve-Zacheo, 1979; Bos \& Loof, 1984) and from soil under old mango and baoba tree in Kenya (Coomans \& Hens, 1997). In Iran, this species was first observed by Fadaei et al. (2003) from rhizosphere of citrus trees in Hormozgan. The present Iranian females conformed well in most morphological and morphometric characteristics to $X$. oxycaudatum described by Lamberti \& Bleve-Zacheo (1979) except in having wider lip region $(10.5-11.5$ vs $9-10 \mu \mathrm{m})$. The main features of the specimens, also fit perfectly to those populations described by Fadaei et al. (2003) except in having slightly greater $\mathrm{c}$ ratio $(50-54$ vs $37-51.5)$ and moderately greater $c^{\prime}$ value $(1.3-1.4$ vs $1.5-1.8)$.

\section{Xiphinema pachtaicum (Tulaganov, 1938) Kirjanova, 1951}

\section{(Figs. 3)}

Measrements

See Table 1.

\section{Distribution}

Robat Namaki village, Robat area, Khorramabad County, Lorestan

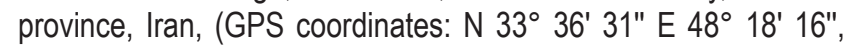
altitude $1332 \mathrm{~m}$ a.s.I.), in the root zone soil of Hawthorn (Crataegus aronia L.).

\section{Remarks}

Xiphinema pachtaicum is a well-known species of worldwide distribution and is probably the most cosmopolitan representative of the $X$. americanum- group. This species is widely distributed throughout the Mediterranean Basin and in Central Asia. It has also been collected from California and Switzerland, England, and South Africa (Lamberti \& Bleve-Zaheo., 1979). Furthermore it is widespread in several countries of Central and Eastern Europe, such as Bulgaria, Croatia, the Czech Republic, Macedonia, Montenegro and Serbia, Moldavia and Ukraine and Slovakia (Repaci et al., 2008). In Iran, X. pachtaicum was first reported from vineyards in East Azarbaijan, West Azarbaijan, Tehran, Esfahan, Lorestan, Khorasan, Sistan and Baluchestan by Mojtahedi et al. (1980), later this species was collected from Ardabil, Kerman, Markazi, Alborz, Kurdistan, Gilan, Zanjan and Hormozgan of Iran from the root zone soil of Beet, Fruit trees, Olive, Potatoe, Tomatoe, Alfalfa, Pistachio, Apricot, Pine, Bean, Walnut and Forest trees (Ghaderi et al., 2018). The Khorramabad population entirely matches with the earlier described populations by Lazarova et al., 2016.

\section{Refrences}

Archidona-Yuste, A., Navas-Cortes, J.A., Cantalapiedra-Navarrete, C., Palomares-Rius, J.E., Castlllo, P. (2016): Cryptic diversity and species delimitation in the Xiphinema americanum-group complex (Nematoda: Longidoridae) as inferred from morphometrics and molecular markers. Zool J Linn Soc., 176(2): 231 - 265. DOI: 10.1111/zoj.12316
Bos, W.S., Loof, P.A.A. (1984): Nigerian species of the genus Xiphinema Cobb, 1913 (Nematoda: Dorylaimida): part I. Nematologica, 30(4): 395 - 418.

BRown, D.J.F., BOAG, B. (1988): An examination of methods used to extract virus vector nematodes (Nematoda: Longidoridae and Trichodoridae) from soil samples. Nematol Mediterr., 16(1): 93 -99 Brown, D.J.F., Faria, A.A., Lamberti, F., Halbrendt, S.M., Agostinelli, A., Jones, A.T. (1992): A description of Xiphinema madeirense $\mathrm{n}$. $\mathrm{sp}$. and the occurrence and virus vector potential of $X$. diversicaudatum (Nematoda, Dorylaimida) from Santana, Madeira. Nematol Mediterr., 20(1992): 251 - 259

Coomans, A., Heyns, J. (1997): Three species of the Xiphinema americanum-group (Nematoda: Longidoridae) from Kenya. Nematologica, 43(5): 259 - 274. DOI: 10.1163/005025997X00021 DE GRISSE, A.T. (1969): Redescription ou modification de quelques techniques utilisées dans l'étude des nematodes phytoparasitaires [Redescription or modification of some techniques used in the study of phytoparasitic nematodes]. Mededelingen Rijksfaculteit Landbouwwetenschappen, Gent, 34: 351 - 369 (In French)

Fadael, A., Coomans, A., Kheirl, A. (2003): Three species of the Xiphinema americanum lineage (Nematoda: Longidoridae) from Iran.Nematol.,5(3):453-461.DOI:10.1163/156854103769224430 GHaderI, R., Kashi L., Karegar, A. (2018): Plant-parasitic nematodes in Iran. Marja-e-elm with Iranian Society of Nematology. 754 pp.

Gutiérrez-Gutiérrez, C., Bravos, M.A., Santos, M.T.,Vieira, P., MotA, M. (2016): An update on the genera Longidorus, Paralongidorus and Xiphinema (Family Longidoridae) in Portugal. Zootaxa, 4189: 99 - 114. DOI: 10.11646/zootaxa.4189.1.4

Gutiérrez-Gutiérrez, C., Cantalapiedra-Navarrete, C., Decraemer, W., Vovlas, N., Prior, T., Palomares-Rius, J.E., Castillo, P. (2012): Phylogeny, diversity, and species delimitation in some species of the Xiphinema americanum-group complex (Nematoda: Longidoridae), as inferred from nuclear and mitochondrial DNA sequences and morphology. Eur. J. Plant Pathol., 134(3): 561 - 597. DOI: 10.1007/s10658-012-0039-9

Lamberti, F., Bleve-Zacheo, T. (1979): Studies on Xiphinema americanum sensu lato with description of 15 new species (Nematoda, Longidoridae). Nematol Mediterr., 7: 51 - 106

Lamberti, F., Molinari, S., Moens, M., Brown, D.J.F. (2000): The Xiphinema americanum group. I. Putative species, their geographical occurrence and distribution, and regional polytomous identification keys for the group. Russ J Nematol., 8(1): 65 - 84

Lazarova, S., Peneva, V., Kumarl, S. (2016): Morphological and molecular characterisation, and phylogenetic position of $X$. browni sp. n., $X$. penevi sp. n. and two known species of Xiphinema americanum-group (Nematoda, Longidoridae). ZooKeys, 574: 1-42. DOI: $10.3897 /$ zookeys.574.8037

Mobasseri, M., Hutchinson, M.C., Afshar, F.J., Pedram, M. (2020): New evidence of nematode-endosymbiont bacteria coevolution based on one new and one known dagger nematode species of Xiphinema americanum-group (Nematoda, Longidoridae). PloS one, 14(6): 1 - 33. DOI: 10.1371/journal.pone.0217506 
Mojtahedi, H., Sturhan, D., Akhianl, A., Barootl, S. (1980): Xiphinema species in Iranian vineyards. Nematol Mediterr., 8: $165-170$

Naghavi, A., Niknam, G., Vazlfeh, N. (2018): Thirteen species of Longidoridae family from East Azarbaijan province. Iran. Procceding of 23st Iranian Plant Protection Congress, Volume II Plant Diseases, Gorgan University of Agricultural Sciences and Natural Resources, 797 - 798

Orlando, V., Chitambar, J.J., Dong, K., Chizhov, V.N., Mollov, D., Bert, W., SubBotin, S.A. (2016): Molecular and morphological characterisation of Xiphinema americanum-group species
(Nematoda: Dorylaimida) from California, USA, and other regions, and co-evolution of bacteria from the genus Candidatus xiphinematobacter with nematodes. Nematol., 18(9): 1015 - 43. DOI: 10.1163/15685411-00003012

Repasi, V., Agostinelli, A., Nagy, P., Colro, M.I., Hecker, K., Lamberti, F. (2008): Distribution and morphometrical characterization of Xiphinema pachtaicum, $X$. simile and $X$. brevicollum from Hungary. Helminthologia, 45: 96 - 102. DOI: 10.2478/s11687-008-0018-z

TAYLOR, C.A., BRown, D.J.F. (1997): Nematode vectors of plant viruses. $2^{\text {nd }}$ Edition, Wallingford, UK, CABI Publishing, $635 \mathrm{pp}$. 